\title{
Pakistan's Industrial Experience and Future Directions
}

\begin{abstract}
A. R. KEMAL
This paper examines the growth and patterns of industrial production and investment activities in Pakistan during the last fifty years, 1947-1997. The industrial strategies pursued so far and the levels of efficiency and protection in the manufacturing industries are also examined. It shows that the growth rate of the manufacturing sector exceeded 8 percent up to the 1980s, but in the recent years, it has slipped to around 3 percent. Keeping in view the current sluggish output growth and inadequate investments in the industrial sector, it is recommended that Pakistan must pursue the efficient industrialisation strategy. For this purpose, the country has to pursue the sole objective of accelerating the pace of industrial investment activities and the tariff structure has to be changed in such a way that the activities chosen accord with her dynamic comparative advantage. In addition, the government will need to influence the structure of incentives, which are largely governed in Pakistan by the protection structure. The government must provide the necessary physical and social infrastructure for efficient industrialisation. Augmenting the science and technology apparatus of the private sector, bringing research institutions up to the international standards, and streamlining of technology creation, absorption and diffusion systems are essential to diversify production towards new technology-based industries. Cluster approach (i.e., an agglomeration of key industries, supporting sectors, infrastructures, and institutions that are interlinked and interdependent) can be quite useful in the development of vendors. The regulatory framework needs to be streamlined. There is also a need to improve outdated and overlapping laws regarding the industrial sector. Human resource development (through cluster approach) would improve industrial efficiency through innovations. Consistent and stable policies and improved law and order situation are pre-requisites for efficient industrial development in Pakistan.
\end{abstract}

\section{INTRODUCTION}

Pakistan's manufacturing sector is at the crossroads. The import substitution industrial strategy which she has all along pursued did result in the growth rate of the manufacturing exceeding 8 percent upto the Eighties, but in recent years, not only the growth rate has slipped to around 3 percent, major structural problems have also emerged in the industrial sector. Lack of diversification in the industrial output, limited exposure to competition, a distorted incentive structure, allocative, technical and $\mathrm{x}$ inefficiencies, negligible growth in productivity, absence of R\&D, lack of quality and standardised products, constrained employment growth, etc., have forced Pakistan to

A. R. Kemal is Chief Economist, Ministry of Planning and Development, Planning and Development Division, Islamabad.

Author's Note: An earlier version of the paper was read at a conference organised by Applied Economics Research Centre, Karachi in December, 1997. 
look for alternative strategies. The export-oriented industrialisation strategy, employment-oriented strategy, and technology-based industrial growth are being contemplated as the alternative strategies.

Sluggish growth of output and inadequate investments in the manufacturing output in recent years are the symptoms of deep-rooted problems from which the sector is suffering. The present study analyses the growth and the pattern of output and investment, as well as efficiencies, in the perspective of industrial strategies with a view to suggesting future industrialisation strategies.

The plan of the paper is as follows. After this introductory section, the growth and pattern of industrial production and investment are examined in Section II. The industrial strategies pursued so far are examined in Section III. Levels of efficiency and the protection to manufacturing industries of Pakistan have been analysed in Section IV. Prospects of industrial growth are examined in Section V.

\section{GROWTH OF OUTPUT AND INVESTMENT IN THE MANUFACTURING SECTOR OF PAKISTAN}

\section{Growth and Pattern of Output}

At the time of independence there were only a handful of large scale manufacturing units in the country. Growing at a rate of 9.1 percent over the 1949-50 to 1996-97 period, the share of large scale manufacturing sector in GDP has risen from 2.2 to 11.7 percent. $^{1}$ The small scale industries over this period have grown at a rate of 5.4 percent ${ }^{2}$ while the manufacturing sector as a whole grew by 7.2 percent. The share of manufacturing sector, both small and large scale, in GDP has increased from 7.8 percent in 1949-50 to 17.9 percent in 1996-97 (See Tables 1 and 2).

Table 1

Growth Rate of the Manufacturing Sector

\begin{tabular}{lccc}
\hline Period & $\begin{array}{c}\text { Small-scale } \\
\text { Manufacturing Sector }\end{array}$ & $\begin{array}{c}\text { Large-scale } \\
\text { Manufacturing Sector }\end{array}$ & $\begin{array}{c}\text { Total Manufacturing } \\
\text { Sector }\end{array}$ \\
\hline $1950-60$ & 2.3 & 15.4 & 7.7 \\
$1960-70$ & 2.9 & 13.3 & 9.9 \\
$1970-80$ & 7.9 & 3.9 & 4.8 \\
$1980-90$ & 8.4 & 8.1 & 8.2 \\
$1990-97$ & 8.4 & 3.5 & 5.0 \\
$1950-95$ & 5.4 & 9.1 & 7.2 \\
\hline Source: Government of Pakistan (Various Issues). \\
19he share of large-scale manufacturing sector had increased to 12.7 percent in 1989-90, but because \\
industrial growth rate has fallen since then, its share has declined. \\
No survey results have been available after 1983-84 for small-scale industries and, as such, growth \\
since then is assumed at 8.4 percent, on the assumption that the growth rate observed in 1976-77 to 1983-84 \\
holds for later periods.
\end{tabular}


Table 2

Percentage Share of Manufacturing in GDP (At Constant Prices)

\begin{tabular}{lccc}
\hline Period & $\begin{array}{c}\text { Small-scale } \\
\text { Manufacturing Sector }\end{array}$ & $\begin{array}{c}\text { Large-scale } \\
\text { Manufacturing Sector }\end{array}$ & $\begin{array}{c}\text { Total Manufacturing } \\
\text { Sector }\end{array}$ \\
\hline $1949-50$ & 5.5 & 2.2 & 7.8 \\
$1959-60$ & 5.1 & 6.9 & 12.0 \\
$1969-70$ & 3.5 & 12.5 & 16.0 \\
$1979-80$ & 4.6 & 12.4 & 17.0 \\
$1989-90$ & 4.9 & 12.7 & 17.6 \\
$1996-97$ & 6.2 & 11.7 & 17.9 \\
\hline
\end{tabular}

Source: Government of Pakistan (Various Issues).

The growth rates of manufacturing sector have been quite uneven over different time periods. The large-scale manufacturing output grew at a rate of 15.4 percent during the 1950s, though it was largely affected by the low base. It continued its momentum in the 1960s when it grew at a rather high rate of 13.3 percent. Due to a number of factors including the structural problems, such as inefficiency and lack of diversification, the dislocation of industries as a result of loss of the East Pakistan market, nationalisation of the industrial sector, and oil shocks, the growth rate fell to just 3.9 percent in the 1970s. Growth rate of manufacturing output increased to 8.1 percent during the 1980s mainly due to an improvement in productivity of the public sector enterprises and overall improvement in productivity as a result of deregulation and import liberalisation. The growth rate slipped to just 3.5 percent in the 90s and in 1996-97, output of large scale manufacturing in fact declined. ${ }^{3}$ A number of factors are responsible for the decline in the growth rate in the 90s. These include restructuring of the industrial sector following reduction in production, deflationary tendencies in the economy, inconsistent policies, lower level of investment and poor law and order situation. The reduction in sales taxes, provision of credit, rationalisation of tariffs and, above all, good sugarcane production lead the growth rate to 5.5 percent in 1997-98.

Small-scale manufacturing sector in the 1950s and the 1960s grew at the rates of only 3.2 percent and 2.9 percent, not only because all the incentives were focused on the large-scale manufacturing but also became the small-scale sector was discriminated against, in the sense that they had to purchase raw materials at relatively higher cost. During the 1970s, the growth rate of the small-scale sector increased to 7.9 percent, which increased further to 8.4 percent in the subsequent periods. The increase in the growth rate of small-scale sector owes a great deal to exemptions from sales taxes and excise duties and better access to imported inputs. Unfortunately, recent data on the sub-

\footnotetext{
${ }^{3}$ The growth rate, however, increased to 8.5 percent in the first 10 months of 1997-98.
} 
sector is not available and it is assumed that small-scale industries continue to grow at a rate of 8.4 percent. There is some evidence to suggest that this growth rate may have been underestimating the true growth rate of the sub-sector [Kemal (1997)].

Not only has the manufacturing sector exhibited high growth rate, there has also been diversification of industrial output, albeit at a slow pace. The removal of quantitative restrictions, lifting of import bans, and reduction in tariff rates on the import of raw materials and intermediate goods during the 1980s have diversified, the manufacturing output, even if only a little. The greater availability of imported raw materials and intermediate inputs at lower prices enabled more intensive use of capital in the import of intensive industries. This also raised the profitability and, as such, investment flowed into import-intensive industries. The share of traditional and indigenous raw material-based industries in the value-added in total manufacturing in 1980-81, 1987-88, and 1990-91 shows a declining trend, though they still account for almost three-fifths of value-added. Their share amounted to 71.0, 671.5, 50.6, 64.5, 52.4, and 58.7 percent of the value-added in 1954, 1959-60, 1969-70, 1980-81, 1985-86, and 1990-91, respectively (see Table 3).

\section{Growth of Industrial Investment}

Data on investment in the manufacturing sector during the 1950s is not available though it is generally presumed that, as a percentage of GDP, it was relatively small. It reached a maximum of 5.0 percent in 1964-65, but by 1969-70 it had already declined to 3.3 percent, and by 1974-75 further to 2.3 percent of GDP. (See Table 4.) Mainly because of public sector investment in various industries including fertiliser and engineering, investment increased to 4.3 percent in 1979-80. In the 1980s, public sector investment was deliberately kept low to accommodate private sector investment. However, total investment fell to 2.7 percent of GDP in 1984-85 because private sector investment could not compensate for the decline in public investment. By 1989-90 it increased to 3.7 percent, but in subsequent years it declined and by 1996-97, it was just 2.7 percent of GDP. ${ }^{4}$

Decline in investment in the manufacturing sector in the post-1965 period may be attributed to three main factors. First, capital inflows fell sharply, and investment in Pakistan is constrained by the availability of investible funds. Second, the manufacturing sector suffered from lack of demand; the inefficient industrial sector developed behind the steep wall of protection was unable to compete in the export market and domestic demand was insufficient for adequate growth of traditional industries. Third, private sector was shy in investing in new industries, and in the existing industries room for expansion was rather limited. Even though nationalisation did scare away the private sector, the investment in the manufacturing sector had already started falling long before the advent of nationalisation policies. It may be further noted that despite private sectorfriendly policies, the investment in manufacturing as a percentage of GDP is still around 2.7 percent of GDP.

${ }^{4}$ Total investment in manufacturing in 1992-93 increased to 4.7 percent. 
Table 3 
Table 4

Investment in Manufacturing Industries during the Eighties

\begin{tabular}{lcccc}
\hline & \multicolumn{3}{c}{$\begin{array}{c}\text { Investment in Manufacturing } \\
\text { as Percent of GDP }\end{array}$} & $\begin{array}{c}\text { Share of Private } \\
\text { Investment in Total } \\
\text { Year }\end{array}$ \\
\cline { 2 - 4 } Private & Public & Total & 96.6 \\
\hline $1963-64$ & 4.6 & 0.2 & 4.8 & 90.6 \\
$1964-65$ & 4.5 & 0.5 & 5.0 & 88.6 \\
$1969-70$ & 2.9 & 0.4 & 3.3 & 57.4 \\
$1974-75$ & 1.3 & 1.0 & 2.3 & 34.7 \\
$1979-80$ & 1.5 & 2.8 & 4.3 & 72.1 \\
$1984-85$ & 2.0 & 0.8 & 2.7 & 88.0 \\
$1989-90$ & 3.3 & 0.4 & 3.7 & 80.8 \\
$1994-95$ & 2.2 & 0.5 & 2.7 & 77.4 \\
$1996-97$ & 2.7 & 0.4 & 3.0 & \\
$1997-98$ & 2.9 & 0.1 & 3.0 & \\
\hline
\end{tabular}

Source: Census of Manufacturing Industries (Various Issues).

\section{The Sources of Growth in the Manufacturing Industries}

Import substitution has played a major role in the growth of manufacturing industries of Pakistan during its earlier stages of development. During the period 195152 to 1954-55, 96.9 percent of growth was accounted for by import substitution and the contribution of export expansion, and the increase in domestic demand was negligible. However, since 1954-55, it has never been a major source of the manufacturing growth. Export expansion has been as important as import substitution but both were overshadowed by the increase in domestic demand. In the 1988-89 to 1991-92 period, however, export expansion was a major source of industrial growth. (See Table 5.) The recession in domestic demand and stagnant exports have constrained the manufacturing growth. (See Table 6.)

That only one-quarter of the growth could be attributed to import substitution in the period upto 1970-71, and even less later, in the case of Pakistan may be contrasted with the results reported in Chenery and Taylor (1968), that import substitution typically accounted for about one-half of the growth of manufacturing output as per capita income grew from 100 dollars to 600 dollars. It also suggests that the recent decline in the manufacturing output may have been due to the slackness in demand. 
Table 5

Sources of Manufacturing Growth

\begin{tabular}{lccc}
\hline Period & $\begin{array}{c}\text { Domestic } \\
\text { Demand }\end{array}$ & $\begin{array}{c}\text { Export } \\
\text { Expansion }\end{array}$ & $\begin{array}{c}\text { (Percentage) } \\
\text { Substitution }\end{array}$ \\
\hline 1951-51 to $1954-55$ & 2.4 & 1.8 & 96.6 \\
1954-55 to 1959-60 & 53.1 & 24.0 & 22.9 \\
1959-60 to 1963-64 & 95.7 & 4.6 & -0.3 \\
1963-64 to 1970-71 & 60.0 & 15.0 & 25.0 \\
1980-81 to 1988-89 & 79.7 & 10.2 & 10.1 \\
1988-89 to 1991-92 & 60.4 & 37.9 & 1.7 \\
\hline
\end{tabular}

Source: Khan (1964); Lewis (1970); Kemal (1990, 1993).

Table 6

The Average Implicit Effective Protection Rates and the Domestic Resource Cost

\begin{tabular}{lcc}
\hline & IEPRs & DRCs \\
\hline $1968-69$ & 125 & 1.20 \\
$1980-81$ & 66 & 3.33 \\
$1990-91$ & 77 & 1.44 \\
\hline
\end{tabular}

Source: Kemal (1978), Naqvi and Kemal (1991, 1998).

\section{CHANGES IN INDUSTRIAL INEFFICIENCY}

Because of the high rate of protection and distortions in the system, value-added in the manufacturing sector is grossly over-stated. The contribution of manufacturing sector at the world market prices is only fractional, reflecting gross inefficiencies and/or excessive profits. The average rate of effective protection ${ }^{5}$ was as high as 271 percent in 1963-64 [See Lewis and Guisinger (1968) and Little, Scitovsky and Scott (1970)]. It fell to 125 percent in 1968-69 [See Kemal (1978)] and to 66 percent in 1980-81 [See Naqvi and Kemal (1991)], but increased once again to 77 percent in 1990-91 [See Naqvi and Kemal (1998)]. ${ }^{6}$ Domestic Resource Cost, which measures the level of inefficiency, fell from very high levels in 1963-64 to around 1.20 in 1968-69, but increased to 3.33 percent by 1980-81. DRCs declined sharply, however, to 1.44 percent in 1990-91.

${ }^{5}$ All the EPRs refer to Corden definition.

${ }^{6}$ The high rates of protection in 1963-64 and 1968-69 indicate to some extent the over-valuation the of rupee. 
An analysis of changes in the level of efficiency in different time-periods is quite revealing. Efficiency improved significantly during the 1960s as a result of import liberalisation, deregulation and de-control policies. Total factor productivity grew at a rate of 5 percent per annum, i.e., 40 percent of growth was contributed by improvement in productivity. DRCs declined to 1.20 and it was also accompanied with somewhat decline in the effective protection rates. Efficiency levels fell once again in the 70s due to a number of factors enumerated earlier notably nationalisation and institution of regulations and controls in the economy once again. The liberal import policy and deregulation in the 1980s resulted in efficiency, though quantitative estimates of total factor productivity are not available. Nevertheless, the DRC declined to 1.44 percent but, paradoxically, the average effective protection rates also increased. This paradoxical result may be explained by noting that the increase in average EPRs may have been due to the fact that in 1990-91, except for three industries the industries did not suffer from negative protection. On the other hand, efficiency was mainly contributed by liberal import policy, especially relating to intermediate goods and raw materials and deregulation and de-control policies.

A detailed analysis of the relationship between efficiency and effective protection rates is quite revealing. Besides 9 negative value-added industries, there were 40 inefficient industries in 1980-81 which were the most protected industries. On the other hand, fourteen inefficient industries were penalised, and probably they remained in business due to government subsidies. All in all, 13 industries were efficient, out of which 4 were protected and nine were negatively protected. The fact that out of 66 inefficient industries 48 had a very high rate of effective protection, and out of 13 efficient industries 9 were penalised, indicates the negative relationship between efficiency and protection. (See Table 7.)

Table 7

Degree of Protection and Level of Inefficiency in the Manufacturing Sector: 1980-81

\begin{tabular}{|c|c|c|c|c|c|c|}
\hline & $\begin{array}{l}\text { Negative } \\
\text { Value }\end{array}$ & $\begin{array}{c}\text { IEPR> } \\
\text { Average }\end{array}$ & $\begin{array}{c}\text { Average } 50< \\
\text { IEPR }\end{array}$ & $0<\mathrm{IEPR}<50$ & IEPR $<0$ & Total \\
\hline Negative Value-added & 9 & - & - & - & - & 9 \\
\hline \multicolumn{7}{|l|}{ Extremely Inefficient } \\
\hline $\mathrm{DRC}>2.0$ & - & 34 & 3 & - & 4 & 41 \\
\hline \multicolumn{7}{|l|}{ Highly Inefficient } \\
\hline $2.0 \geq \mathrm{DRC}>1.50$ & - & 1 & - & 5 & 4 & 10 \\
\hline \multicolumn{7}{|l|}{ Very Inefficient } \\
\hline $1.50 \geq \mathrm{DRC}>1.25$ & - & 2 & - & 1 & 3 & 6 \\
\hline $\begin{array}{l}\text { Moderately Inefficient } \\
1.25 \geq \text { DRC }>1.00\end{array}$ & - & 0 & - & 2 & 1 & 3 \\
\hline $\mathrm{DRC} \leq 1.00$ & - & 1 & - & 3 & 9 & 13 \\
\hline Total & 9 & 38 & 3 & 11 & 21 & 82 \\
\hline
\end{tabular}

Source: Naqvi and Kemal (1998). 
In 1990-91, besides 12 value-added industries, there were 3 inefficient industries and they were all protected. Out of 45 efficient industries, only three enjoyed negative protection. (See Table 8.) This shows, once again, the negative relationship between efficiency and protection. Another important result noted in Kemal (1993) is that the efficient industries have grown at a faster rate compared to the other industries. This also shows why efficiency improved over the 1980-81 to 1990-91 period despite rising rates of effective protection. While the levels of efficiency did improve, processing cost in 1990-91 was still 44 percent higher than the world prices.

Table 8

The Number of Industries by Efficiency Levels and Protection: 1990-91

\begin{tabular}{|c|c|c|c|c|c|c|}
\hline & $\begin{array}{l}\text { Negative } \\
\text { Value }\end{array}$ & $\begin{array}{l}\text { IEPR> } \\
\text { Average }\end{array}$ & $\begin{array}{l}\text { Average } \\
50<\text { IEPR }\end{array}$ & $0<\mathrm{IEPR}<50$ & IEPR $<0$ & Total \\
\hline Negative Value-added & 12 & - & - & - & - & 12 \\
\hline Extremely Inefficient & & & & & & \\
\hline $\mathrm{DRC}>2.0$ & - & 6 & - & - & - & 6 \\
\hline Highly Inefficient & & & & & & \\
\hline $2.0 \geq \mathrm{DRC}>1.50$ & - & 3 & - & - & - & 3 \\
\hline Quite Inefficient & & & & & & \\
\hline $1.50 \geq \mathrm{DRC}>1.25$ & - & 2 & - & - & - & 2 \\
\hline $\begin{array}{l}\text { Moderately Inefficient } \\
1.25 \geq \text { DRC }>1.00\end{array}$ & - & - & 1 & 1 & - & 3 \\
\hline $\mathrm{DRC} \leq 1.00$ & - & 28 & 1 & 13 & 3 & 45 \\
\hline Total & 11 & 34 & 3 & 14 & 3 & 70 \\
\hline
\end{tabular}

Source: Naqvi and Kemal (1998).

The social costs of protection have been estimated alternately on the basis of two definitions. First, the cost of protection, defined as the wasteful use of domestic resource in the activity of earning (saving) foreign exchange, amounted to 9.9 percent of the GDP in 1980-81 and 3.9 percent of the GDP in 1990-91. Second, cost defined as the increase in the share of the manufacturing sector in the GDP due to protection, measured at world market prices, amounted to 5.7 percent of the GDP in 1980-81 and to 5.0 percent of the GDP in 1990-91. Both the measures indicate a sharp decline in the cost of protection to the economy.

\section{INDUSTRIALISATION STRATEGIES}

Whereas Pakistan has all along pursued import substitution industrial strategy, one finds that protection rates and the methods to provide protection have varied significantly over different time-periods. This has led to varied manufacturing industries in different time-periods. 
The industrial policy of the 1950s aimed at processing the indigenous raw materials such as cotton, jute, hides and skins, etc., and at manufacturing those products for which she was heavily dependent on imports. Imports, investments, and prices were subject to direct controls during the 1950s which created rigidities ${ }^{7}$ in the system and hampered the investment and levels of efficiency. Too much emphasis was placed on the reduction in imports, and too little on increasing the export earnings, which is manifested in the fact that the exchange rate was overvalued and there were no subsidies to the export to offset the tariffs and non-tariff barriers on imports. ${ }^{8}$

During the 1960s, price controls were lifted from almost all the products, foreign exchange market was liberalised, exports were subsidised, and fiscal incentives in the form of tax holidays and accelerated depreciation allowances were granted. These measures resulted in a rather high growth rate of 13.3 percent and a sharp increase in the level of efficiency. Total factor productivity increased at a rate of 5 percent but most of the increase was used to increase the rate of return rather than reduction in prices. The protection rates remained high and dispersion continued to be quite large. There was very little diversification and exports possibilities of traditional industries was limited. The emergence of structural problems ${ }^{9}$ in the manufacturing sector by the end of $60 \mathrm{~s}$ resulted in a reduction in the investments.

A number of measures taken during the 1970s have a long-run bearing on the industrialisation process. Nationalisation of heavy industry, reserving exclusively cement, fertiliser, oil refining, engineering and chemicals industries for the public sector, price controls under the Profiteering and Hoarding Act, withdrawal of fiscal incentives and export subsidies, reduction in import duties on finished goods, and anti-monopoly measures eroded incentives for private sector investment. Low levels of profits amid uncertainty resulted in a massive flight of capital. Consequently, investment in manufacturing, and particularly private investment as a percentage of GDP, fell. ${ }^{10}$ On the other hand, devaluation of the rupee reduced significantly the multiplicity of exchange rates and provided level playing fields to the large- and small-scale industries. Because small-scale industries had equal access to the imported inputs, the growth rate of small industries increased. Moreover, unification of the exchange rate made them competitive in the export market.

${ }^{7}$ Because manufacturing industries in Pakistan were heavily dependent on imports for their requirements of capital and intermediate goods, rigid import quotas neither let the optimal allocation of investment nor let the industries to use their capital at an optimal level of intensity. Similarly, price controls left fewer incentives to expand production in the most profitable branches of production.

${ }^{8}$ For details of the policies and impact on industries see Naqvi (1963); Khan (1964); Lewis and Soligo (1965); Lewis (1969); Lewis and Soligo (1965a) and Papanek (1967).

${ }^{9}$ For detailed analysis see Islam (1967), Lewis (1969, 1970), Lewis and Guisinger (1968), Little, Scitovsky and Scott (1970); Papanek (1967); Soligo and Stern (1963); Naqvi (1965, 1971); Pal (1964, 1965); Thomas (1966); Kemal (1978).

${ }^{10}$ For details of policy initiatives and growth in the 70s, see Azhar and Sharif (1974), Kemal and Alvi (1975), Naqvi and Sarmad (1984) and Naqvi and Kemal (1991). 
During the 1980s and 1990s, direct controls have been replaced with marketoriented forces; import policy has been liberalised; tariff structure has been rationalised; and maximum import duty has been reduced to 45 percent; export duties on raw cotton and cotton yarn have been removed; and certain other facilities are being provided to exporters. Fixed exchange rate system has been replaced with managed float, investment has been deregulated, prices have been de-controlled, and public enterprises have been divested. These measures did result in improvement in productivity. As DRC fell to 1.44 does, but estimates of growth of productivity are not available.

During the 1980s Pakistan also actively encouraged foreign private investment especially to affect transfer of technology. With a view to encouraging assembly-cummanufacturing, government provides incentives to assemblers through lower import duties on components provided they agree to a programme of indigenisation called the 'deletion programme'. While some transfer of technology except motor vehicles has taken place, there is a danger that the cost of transfer of technology may have been prohibitive. Reliance on penalties for defaulters can hardly ensure efficient indigenisation. ${ }^{11}$

\section{STRATEGY AND FUTURE OPTIONS OF THE MANUFACTURING SECTOR}

The emergence of structural problems and consequently reduction in investments and growth of output necessitate a closer look at the industrial policy of Pakistan. While deregulation and import liberalisation have already led to improvements in the levels of efficiency and diversification of the industrial sector, the pace of improvement has been relatively slow. Even in 1990-91, processing cost, on average, was 44 percent higher than the world level. The future strategy has to bring the levels of DRCs down, even further and the manufacturing sector has to move into new areas where high growth rates can be sustained.

Inconsistent and frequent changes in the policies besides inadequate infrastructures and the law and order situation have been responsible for the low levels of investment. Obviously, policy formulation to serve inconsistent objectives is not possible. In the past, regional development has always been given an over-riding consideration in the industrial policies. While the policies failed to realise the objective, they resulted in distortions in the system. Pakistan must pursue only efficient industrialisation as the country can no longer afford the luxury of sacrificing efficiency for regional industrialisation.

Pakistan has to pursue the sole objective of accelerating the pace of industrial investment in activities which accord with her dynamic comparative advantage. To the extent that dynamic and static comparative advantages differ, the government will have

\footnotetext{
${ }^{11}$ For details of policies and their impact on manufacturing industries during this policy, see IMG Consultants (1988); Kemal (1990, 1993); Kemal, Mahmood and Ahmed (1993); Naqvi and Kemal (1998).
} 
to influence the structure of incentives, largely governed in Pakistan by the protection structure, which is being rationalised. The rationalising may be carried out to reduce both magnitude as well as dispersion in the effective protection.

Cascading the tariff structure by stages of processing implies that both the infant as well as the mature industries are provided the same incentives. Tariff structure has to be changed in such a way that the activities chosen accord with dynamic and not static comparative advantage. The recently announced investment policy provides more fiscal incentives to the infant industries, which are technology-based and have high valueadded industries. Such a policy would be difficult to operationalise, and one does not know if it would accord with long-run comparative advantage of Pakistan.

While protection structure in accordance with dynamic comparative advantage is necessary for efficient industrialisation, it may not be sufficient. The government has to provide for the necessary physical and social infrastructure and regulatory framework. Augmenting the science and technology apparatus of private sector, bringing research institutions up to international standards, and streamlining of technology creation, absorption, and diffusion systems are essential if Pakistan wants to diversify her production towards new technology-based industries [See DRI/McGraw Hill (1997, 1997a)].

With a view to improving the standardisation and quality of products and to transferring technology, Pakistan has been encouraging foreign private investment. Technology transfer may be effected through indigenisation programmes. These programmes create incentives for the firms to develop vendors. In general, the assemblers have been arguing that there have been no vendors and as such government intervention may be necessary. Cluster approach, i.e., an agglomeration of key industries, supporting sectors, infrastructures, and institutions that are inter-linked and inter-dependent because of some shared technological or skill base, can be quite helpful in the development of vendors. The clusters funds provided by government can be used to carry out contract research which would enhance the technological landscape. As a result, entrepreneurs would use the imported technology in a better way; they would also be able to implement ancillary systems such as quality control, material handling, and the distribution system.

The present industrial structure of Pakistan is based on low skills. Human resource development through cluster approach would improve industrial efficiency through innovations. Obviously, the firms operating in traditional industries have so far innovated very little but these clusters can help them in improving productivity. On the other hand, industries, such as electronic or auto parts, would benefit from these cluster in product design, automation, and inventory control.

The regulatory framework needs to be streamlined. There is a need to improve outdated and overlapping labour laws with new comprehensive laws. Similarly, the Monopolies and Trade Restrictive Practices (Control and Prevention) Ordinance, 1970 needs to be modified; the winding-up procedure for insolvent companies needs to be 
simplified; and patent laws in accordance with present international standards need to be amended.

\section{REFERENCES}

Azhar, B. A., and Shahroukh Sharif (1974) The Effects of Tax Holiday on Investment Decisions: An Empirical Analysis. The Pakistan Development Review 13:4 409-432.

Chenery, H., and L. Taylor (1968) Development Patterns: Among Countries and Over Time. Review of Economics and Statistics 4: 391-416.

DRI/McGraw-Hill (1997) Creating Change through Private Sector-led Industrialisation.

DRI/McGraw-Hill (1997a) Building Pakistan's Technological Competence.

IMG Consultants (1988) Industrial Efficiency Improvement and Development Strategy. Prepared for Government of Pakistan, Islamabad.

Islam, N. (1967) Comparative Cost, Factor Proportions and Industrial Efficiency in Pakistan. The Pakistan Development Review 7:3 213-246.

Kemal, A. R. (1978) An Analysis of Industrial Efficiency in Pakistan: 1959-60 to 1969-70. Unpublished Ph.D. Thesis, University of Manchester.

Kemal, A. R. (1987) Effective Protection Rates: A guide to Tariff Making. The Pakistan Development Review 26:4 775-85.

Kemal, A. R. (1990) Industrial Sector Review of Pakistan. Study prepared for the Asian Development Bank.

Kemal, A. R. (1993) Recent Development in the Manufacturing Sector. Study prepared for the Asian Development Bank.

Kemal, A. R. (1997) Employment and the Manufacturing Sector of Pakistan. SAAT, ILO, New Delhi.

Kemal, A. R., and Z. Alvi (1975) Effect of 1972 Devaluation on Pakistan's Balance of Trade. The Pakistan Development Review 14:1 1-22.

Kemal, A. R., Zafar Mahmood, and Ather Maqsood Ahmed (1994) Structure of Protection, Efficiency and Profitability. Islamabad: Pakistan Institute of Development Economics.

Kemal, A. R., N. A. Burney, and S. Hamid (1981) Quota Restrictions, Tariffs and the Scarcity Premium on Licenses. Pakistan Institute of Development Economics, Islamabad. (Statistical Papers Series No. 2.)

Kemal, A. R., Zafar Mahmood, and Ather Maqsood Ahmed (1993) Protection Structure, Efficiency and Profits in Pakistan. PIDE. Study carried out for Resource Mobilisation Commission.

Khan, A. R. (1964) Import Substitution, Export Expansion and Consumption Liberalisation. The Pakistan Development Review 3:2 208-231.

Lewis, S. (1969) Economic Policy and Industrial Growth in Pakistan. London: George 
Allen and Unwin Ltd.

Lewis, S. (1970) Pakistan: Industrialisation and Trade Policies. Paris: O.E.C.D.

Lewis, S., and Guisinger S. (1968) Protection in a Developing Country-Case of Pakistan. Journal of Political Economy 76:6 1170-1198.

Lewis, S., and R. Soligo (1965). Growth and Structural Change in Pakistan's Manufacturing Industries, 1954-64. The Pakistan Development Review 5:1 94-139.

Lewis, S., and R. Saligo (1965a) Tariff Protection, Import Substitution and Investment Efficiency. The Pakistan Development Review 5:2 249-270.

Little, I. M. D., Scitovsky T., and M. Scott (1970) Industry and Trade in Some of the Developing Countries. Paris: O.E.C.D.

Naqvi, S. N. H. (1963) The Balance-of-Payments Problems and Resource Allocation in Pakistan-A Linear Programming Approach. The Pakistan Development Review 3:3 349-370.

Naqvi, S. N. H. (1971) On Optimising Gains from Pakistan’s Export Bonus Scheme. Journal of Political Economy 79:1 114-177.

Naqvi, S. N. H., and A. R. Kemal (1991) Protectionism and Efficiency in Manufacturing: A Case Study of Pakistan. San Francisco, California: ICS Press. International Centre for Economic Growth and Pakistan Institute of Development Economics.

Naqvi, S. N. H., and A. R. Kemal (1998) The Burden of Protectionism—A Case Study of Pakistan's Manufacturing. Unpublished Manuscript.

Naqvi, S. N. H., and K. Sarmad (1984) Pakistan's Economy through the Seventies. Islamabad: Pakistan Institute of Development Economics.

Pakistan, Government of (Various Issues) Census of Manufacturing Industries. Bureau of Statistics, Islamabad.

Pakistan, Government of (Various Issues) Pakistan Economic Survey. Islamabad: Finance Division, Economic Advisers' Wing.

Pal, M. (1964) The Determinants of the Domestic Prices of Imports. The Pakistan Development Review 4:4 597-622.

Pal, M. (1965) Domestic Prices of Imports in Pakistan: Extension of Empirical Findings. The Pakistan Development Review 5:4 547-585.

Papanek, G. (1967) Pakistan's Development-Social Goals and Private Incentives. Cambridge: Harvard University Press.

Soligo, R., and J. J. Stern (1965) Tariff Protection, Imports Substitution and Investment Efficiency. The Pakistan Development Review 5:2 249-270.

Thomas, P. (1966) Import Licensing and Import Liberalisation in Pakistan. The Pakistan Development Review 6:4 500-544. 